\title{
Literasi Matematika dalam Menyambut PISA 2021 Berdasarkan Kecakapan Abad 21
}

\author{
Habibi $^{1}$, \& Suparman ${ }^{2 *}$ \\ ${ }^{1,2}$ Universitas Ahmad Dahlan, Yogyakarta, Indonesia
}

\begin{tabular}{l} 
INFO ARTICLES \\
\hline Article History: \\
Received: $11-12-2020$ \\
Revised: $19-12-2020$ \\
Approved: $21-12-2020$ \\
Publish Online: $25-12-2020$
\end{tabular}

Key Words:

Mathematical Literacy; PISA; $21^{\text {st }}$ Century Skill;

under a Creative Commons AttibutionShareAlike 4.0 International License.

\begin{abstract}
One of the skills needed in the global era is mathematical literacy. Mathematical literacy refers to an individual's ability to formulate, use, and interpret mathematics in a variety of contexts with mastery of information technology. The international assessment of 15-year-olds' math literacy is measured through PISA (Programme for International Student Assessment) organised by the OECD (Organization for Economic Cooperation and Development). In welcoming PISA 2021 honing students' reasoning skills can be done by habituation to find solutions to test questions that measure high levels of thinking ability.
\end{abstract}

\begin{abstract}
Abstrak: Salah satu kecakapan yang diperlukan di era global adalah literasi matematika. Literasi matematika merujuk pada kemampuan individu untuk memformulasikan, menggunakan, dan menginterpretasikan matematika dalam berbagai konteks dengan penguasaan teknologi informasi. Penilaian literasi matematika siswa usia 15 tahun secara internasional diukur melalui PISA (Programme for International Student Assessment) yang diselenggarakan oleh OECD (Organization for Economic Cooperation and Development). Dalam menyambut PISA 2021 mengasah kemampuan bernalar siswa dapat dilakukan dengan pembiasaan menemukan solusi dari soal-soal tes yang mengukur kemampuan berpikir tingkat tinggi.
\end{abstract}

Correspondence Address: Kampus 2 UAD Jl. Pramuka No. 42, Sidikan, Umbulharjo, Yogyakarta 55161, Indonesia; e-mail: $\underline{\text { suparman@pmat.uad.ac.id }}$

How to Cite (APA $6^{\text {th }}$ Style): Habibi, H., \& Suparman, S. (2020). Literasi Matematika dalam Menyambut PISA 2021 Berdasarkan Kecakapan Abad 21. JKPM (Jurnal Kajian Pendidikan Matematika), 6(1): 57-64.

Copyright: 2020 Habibi Habibi, Suparman Suparman

Competing Interests Disclosures: The authors declare that they have no significant competing financial, professional or personal interests that might have influenced the performance or presentation of the work described in this manuscript. 


\section{PENDAHULUAN}

Tantangan siswa dalam memasuki abad 21 lebih besar daripada generasi terdahulu. Abad 21 sebagai era global mensyaratkan penguasaan terhadap kecakapan literasi, kompetensi, karakter dan tetap dibekali oleh jatidiri bangsa. Jatidiri bangsa tetap harus melekat dalam diri siswa. Dalam membekali jati diri Bangsa, muncul etnomatematika. Tetapi dalam kajian ini, akan lebih fokus dalam literasi matematika. Hal ini mengacu juga pada tataran internasional, mengikuti pedoman National Education Association (2011: 5) menyatakan bahwa untuk berkompetisi di era global, siswa harus menjadi proficient communicators, creators, critical thinkers, dan collaborators. Artinya bahwa siswa dituntut untuk memiliki kecakapan lebih, melebihi sekadar kecakapan membaca, menulis, dan aritmatika. Kecakapan lain yang diperlukan oleh generasi muda di era global adalah karakter. Sementara itu, dalam tataran nasional, melalui Kementerian Pendidikan dan Kebudayaan (2017: 2) menyatakan bahwa kecakapan yang diperlukan pada abad 21 yaitu literasi dasar, kompetensi, dan karakter. Salah satu literasi dasar yang diperlukan adalah literasi matematika.

Posisi siswa dalam perkembangan era abad 21 dituntut untuk mampu menafsirkan/menginterpretasikan konsep-konsep matematika dalam berbagai konteks. Sari (2015) menekankan literasi matematika sebagai kapasitas siswa yang tidak hanya memformulasikan, mengunakan, dan menafsirkan matematika pada persoalan tekstual dalam buku saja, tetapi lebih dari itu dalam berbagai konteks. Dengan begitu, fenomena yang ada dapat diprediksi dengan penalaran matematik dan pengunaan konsep, prosedur, fakta yang dipelajari dalam matematika. Penyajian latihan matematika dalam pembelajaran pun sebagai instrumen untuk membentuk nalar siswa dalam mendeskripsikan, menjelaskan, dan memprediksi konteks nyata. Sehingga penyajian literasi matematika dapat menjadi jalan mengenali peranan matematika dalam kehidupan dan membuat penilaian yang baik dan pengambilan keputusan yang memberikan kemanfaatan dalam keseharian siswa dan lingkungannya.

Literasi matematika juga menuntut siswa untuk mengkomunikasikan dan menjelaskan fenomena yang dihadapinya dengan konsep matematika. Fenomena yang dihadapi masing-masing siswa jelas berbeda-beda, sehingga tiap siswa memiliki keunikan masing-masing. Hal ini dikuatkan oleh Fathani (2016), pada dasarnya, proses pengembangan literasi matematika, harus memperhatikan keunikan siswa pembelajar, yang dalam hal ini kecenderungan kecerdasan yang dimiliki

Penilaian terhadap literasi matematika dilaksanakan melalui PISA (Programme for International Student Assessment) yang diselenggarakan oleh OECD (Organization for Economic Cooperation and Development). Penilaian dilakukan dengan survey di sejumlah negara, tahun 2000, 2003, 2006, 2009, 2012, dan 2015. Hasil survey PISA pada kurun waktu tersebut menunjukkan skor rata-rata literasi matematika masih di bawah skor rata-rata negara-negara lain. Dengan demikian, posisi literasi matematika siswa Indonesia masih di bawah literasi matematika negara-negara lainnya. Berdasarkan Gomes, Hirata, \& Oliveira (2020), PISA merupakan penilaian yang diakui dunia, sehingga hasilnya benar-benar dapat menjadi tolak ukur posisi literasi matematika siswa Indonesia.

Walaupun demikian, Wulandari \& Azka (2018) memberikan gambaran secercah harapan tahun 2015, skor rata-rata literasi matematika mengalami peningkatan. Perbandingannya, tahun 2012 skor rata-rata 375 sedangkan pada tahun 2015 menjadi 386, berarti 11 poin mengalami peningkatan.

Mengacu pada penilaian PISA, Fathani (2016) menginterpretasikan literasi matematika siswa di Indonesia berdasarkan studi internasional masih belum memuaskan. Lebih lanjut, instrument dalam pengukuran literasi juga menjadi masalah tersendiri. Penggunaan pemodelan matematika (pengambilan masalah kontekstual) dengan istilah-istilah yang tidak familiar di Indonesia, menjadi kesulitan tersendiri. Proses pengaitan dengan konsep matematika menjadi terhambat. 
Disampaikan oleh Mansur (2018) konteks keseharian dalam PISA, merupakan fokus dengan literasi yang menekankan pada keterampilan dan kompetensi siswa yang diperoleh dari sekolah dan dapat digunakan dalam kehidupan sehari-hari. Permasalahan yang muncul, konteks keseharian di luar negeri berbeda dengan konteks keseharian di Indonesia. Siswa masih terjebak dalam mengimajinasikan obyek yang ada dalam instrument penilaian, sehingga dalam imajinasi tersebut sangat sulit untuk mengaitkan dengan konsep dalam matematika.

Kondisi literasi matematika dengan penekanan pada konteks keseharian yang berhubungan dengan teknologi memang sudah semestinya. Syawahid \& Putrawangsa (2017) mengemukakan, kompetensi yang dikembangkan dalam literasi matematika di samping kemampuan penalaran, kemampuan pengambilan keputusan, kemampuan pemecahan masalah, kemampuan mengelola sumber, kemampuan menginterpretasi informasi, kemampuan mengatur kegiatan, ada kemampuan yang fokus pada kemampuan menggunakan dan menerapkan teknologi.

Maulana, A., \& Hasnawat, H. (2016) masih menekankan kemampuan dasar matematika siswa berperan penting dalam proses penerapan konsep ataupun prinsip dalam menemukan solusi matematika. Kendala yang ada, kemampuan siswa Indonesia dalam menyelesaikan soal-soal berupa soal telaah, memberi alasan, mengkomunikasikan, dan memecahkan serta menginterpretasikan berbagai permasalahan masih sangat rendah. Kembali pada fokus penyajian instrumen di PISA, menjadi koreksi bersama bahwa soal-soal matematika dalam studi PISA lebih banyak mengukur kemampuan bernalar, memecahkan masalah dan berargumentasi daripada mengukur kemampuan ingatan dan perhitungan. Sementara, beberapa penelitian yang telah dilakukan di beberapa sekolah Indonesia menunjukkan kemampuan siswa masih belum terbiasa dengan soal permasalahan yang membutuhkan pemikiran logis dan aplikatif. Siswa masih menyukai dan terbiasa dengan jawaban teoritis, dan prosedural. Sehingga, pembiasaan soal-soal yang membutuhkan penalaran logis harus dibiasakan pada pembelajaran. Hal ini perlu menjadi perhatian utama untuk program pendidikan Indonesia selanjutnya.

\section{PEMBAHASAN}

Pembahasan dalam artikel ini bersifat kajian teori (kajian pustaka) terhadap referensi dan hasil penelitian yang berkaitan dengan literasi matematika. Penulis menelaah, menganalisis, dan menyusun simpulan berkaitan dengan literasi matematika. Literasi matematika yang erat kaitannya dengan PISA dan kecakapan abad 21.

OECD (2006: 12) memberikan Batasan literasi matematika sebagai kemampuan seseorang untuk mengidentifikasi dan memahami peranan matematika dalam kehidupan, membuat keputusan yang dibangun dengan baik dan menggunakan serta terlibat dalam matematika dengan kepentingan kehidupan individu sebagai penduduk yang konstruktif, peduli dan reflektif. Batasan tersebut memiliki aspek identifikasi, pemahaman, pengambilan keputusan, dan pendayagunaan matematika dalam kehidupan, sehingga ada nilai kemanfaatan dengan kemampuan matematika yang dimiliki. Batasan terkait penggunaan kata keberadaan individu sebagai bagian dari masyarakat dunia yang disebut dengan penduduk, memiliki pengertian matematika juga bermanfaat untuk lingkungan sekitar.

Ojose (2011: 89) memberi pengertian literasi matematika tidak hanya pengetahuan sebatas topologi, aljabar linear, aljabar abstrak, dan rumus matematika yang kompleks dan canggih tetapi lebih kepada sebuah pemahaman yang luas dan penghargaan atas apa yang mampu dicapai dengan matematika. Sehingga bisa diartikan lebih kepada kebermanfaatan matematika dalam kehidupan nyata. Literasi matematika tidak hanya sebatas penguasaan ilmu dan penalaran teori saja.

Berkaitan dengan kebermanfaatan dalam dunia nyata, maka literasi matematika jelas berkaitan dengan konsep pemodelan matematika. Stacey (2010: 8) mengungkapkan konsep literasi matematika berkaitan 
dengan konsep lain meliputi pemodelan matematika dan komponen proses yang oleh de Lange disebut dengan matematisasi. Lebih lanjut Kaiser dan Sriraman (2006: 32) menyebut proses pemodelan dilaksanakan secara utuh, bukan berupa proses parsial.

Proses pemodelan dalam Bahasa lain merupakan proses matematisasi. Penerapan matematika dalam pemecahan masalah. Secara lebih lanjut Stacey (2010: 8) menjelaskan bahwa proses matematisasi berkaitan dengan menyusun (formulating) masalah kehidupan nyata dalam istilah atau notasi matematis sehingga dapat diselesaikan (can be solved) sebagai masalah matematis dan solusi matematisnya dapat diterjemahkan (can be interpreted) untuk menjawab masalah nyata. Seangkan Haines \& Crouch dalam (Kaiser dan Sriraman, 2006: 32) menyatakan bahwa pemodelan dipahami sebagai aktivitas untuk menyelesaikan masalah autentik dan bukan sebagaimana pengembangan teori matematis.

Berkaitan dengan pemodelan matematika, Cai et. al. (2004: 6) menyatakan bahwa pemodelan matematis adalah seni atau proses membangun representasi matematis factual yang menampilkan, menyimulasikan, atau merepresentasikan fitur terpilih atau perilaku dari aspek faktual yang dimodelkan. Hal ini menandakan bahwa pemodelan matematis berfokus pada representasi matematis. Gambar 1. berikut merupakan perbandingan penilaian PISA pada periode sebelumnya.

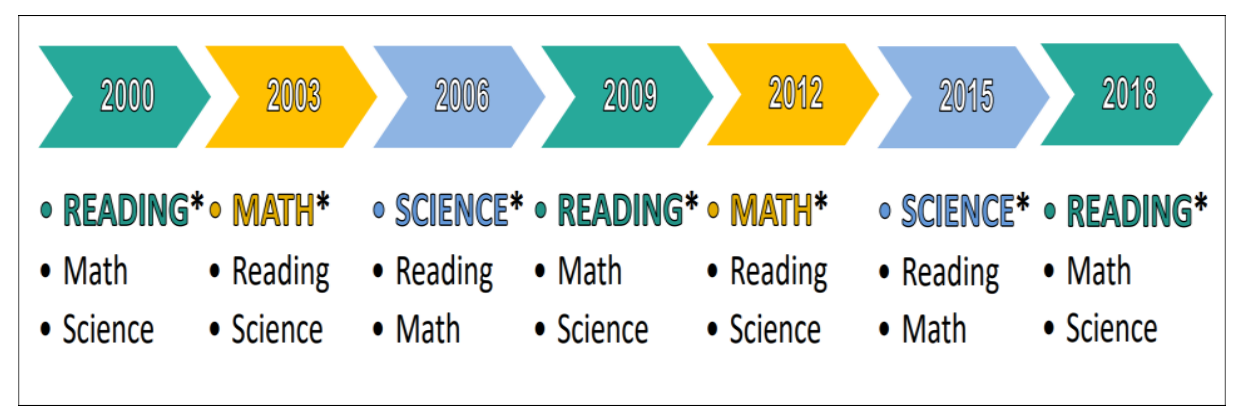

Sumber: The PISA Cycle of Assessments (ed.gov)

\section{Gambar 1. Siklus Penilaian Domain Kognitif PISA}

Gambar 1. Merupakan The PISA Cycle of Assessments, sehingga untuk PISA 2021, fokus penilaiannya atau major domain-nya pada Math (Mathematics Literacy). Mengulas dari Gambar 1. hasil analisis Ehmke, et. al. (2020), item matematika PISA 2012 lebih sulit mengenai tingkat kata dan kompleksitas struktur kalimat. Dalam keterangan Stacey (2011) inovasi untuk PISA 2012, definisi dari literasi matematika direvisi untuk memperjelas konstruksi, memperjelas bahwa literasi matematika tidak dimaksudkan merendahkan tingkat kemampuan berdasarkan pengetahuan dasar dan keterampilan, tetapi juga aspek lain yang individu memiliki, dan membutuhkan berbagai tingkatan. Di sisi lain, adanya penyederhanaan dan klarifikasi namanama berbagai dimensi kerangka kerja dan indikasi konten matematika yang mungkin berguna dalam item PISA, meskipun tidak ada niat untuk secara sistematis menilai silabus apa pun.

Dampak teknologi informasi terhadap literasi matematika semakin menerima perhatian. Penilaian berbasis komputer opsional disertakan di PISA 2012 dikenal dengan istilah collaborative problem-solving skills (CPS). Stadler, et. al. (2020) menyebut bahwa pengukuran dengan instrument collaborative problemsolving skills (CPS) dalam siklus program 2015 dipaparkan terkait kevalidtan CPS. Pemaparan dengan mengidentifikasi sejauh mana penilaian terkait dengan langkah-langkah kolaborasi yang ada, termasuk kolaborasi berbasis diri subjektif, kolaborasi berbasis guru eksternal, kolaborasi rekan sejawat, serta penalaran dan membaca.

Pada tahun 2021 akan dilaksanakan survey PISA yang ke delapan sejak tahun 2000. Survey ini memiliki fokus yang berbeda dengan periode sebelumnya. Domain penilaian pada survey PISA 2021 meliputi literasi membaca, literasi matematika, literasi sains, literasi finansial, dan kompetensi global, serta tambahan literasi terkait computational thinking. Survey tersebut direncanakan paper-based dan computer- 
based matematika, penyelesaian masalah secara kolaboratif menjadi prioritas kedua (minor). Penilaian juga menjadikan finansial literacy sebagai fokus penilaian pada Negara tertentu. Berkaitan dengan literasi matematika, terdapat empat konten yang menjadi penilaian dalam survey PISA, perubahan dan hubungan (change and relationships), ruang dan bentuk (space and shape), kuantitas dan ketidakpastian (quantity and uncertainty) (OECD, 2016: 84). Gambaran terkait 4 konten dalam penilaian survey PISA dapat diperjelas dalam Gambar 2.

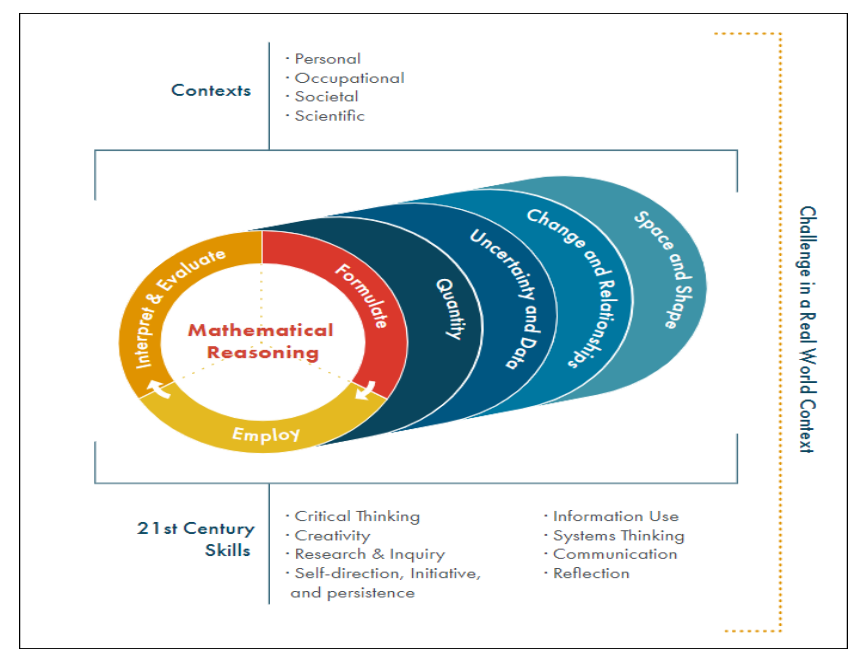

Sumber: https://pisa2021-maths.oecd.org/

\section{Gambar 2. Tantangan Dunia Nyata dan Kecakapan Abad 21}

Mengacu pada Gambar 2., kecakapan abad 21 yang perlu dimiliki adalah critical thinking; creativity; research and inquiry; self-direction, initiative and persistence; information use; systems thinking; communication; and reflection. Gambar 2. Sekaligus merupakan Mathematics Framework dalam menghadapi PISA 2021. Pada PISA 2021 ada aspek yang dimunculkan, yaitu terkait mathematical reasoning.

Rendahnya literasi matematika disebabkan oleh beberapa hal. Faktor- faktor yang memengaruhi prestasi siswa Indonesia pada studi PISA 2012 yaitu latar belakang peserta dari faktor internal yaitu jati diri siswa dan faktor eksternal yaitu kondisi keluarga, kepemilikan sarana belajar, dan kondisi sosial budaya di rumah dengan jati diri, kondisi sosial ekonomi dan budaya, kepemilikan komputer, dan buku-buku merupakan faktor utama yang memengaruhi capaian literasi matematika siswa Indonesia peserta PISA 2012 (Pakpahan, 2016: 331).

Wulandari \& Azka (2018) menyebutkan faktor rendahnya kemampuan pengetahuan matematis dipengaruhi: 1) materi yang dipilih, 2) pembelajaran yang diberikan oleh guru, 3) lingkungan kelas, 4) dukungan lingkungan keluarga, 5) kesiapan dalam pelaksanaan tes dan 6) kemampuan yang dimiliki setiap siswa sendiri. Selanjutnya Mahdiansyah dan Rahmawati (2014) menyatakan bahwa dari aspek konteks, scientific merupakan konteks yang paling rendah dicapai siswa; Adapun soal-soal tes yang mengukur kemampuan berpikir tingkat tinggi (higher orderthinking skills-HOTS) belum mampu dikuasai siswa dengan baik; Terdapat sejumlah faktor determinan dari capaian literasi matematika tersebut, yaitu faktor personal, faktor instruksional, dan faktor lingkungan; Kesimpulan studi adalah literasi matematika siswa jenjang pendidikan menengah masih rendah, meskipun desain tes internasional yang digunakan telah disesuaikan dengan konteks Indonesia.

Tjalla (2010: 14) menyatakan bahwa skor rata-rata kemampuan matematika yang diperoleh siswa Indonesia masih di bawah rata-rata negara lain. Kemampuan bernalar dapat dijadikan modal kesiapan siswa dalam menghadapi PISA 2021. 
Walberg dalam (Topcu, 2016: 1715) mengemukakan model pendidikan yang produktif berguna sebagai framework untuk menguji keterkaitan prestasi matematika dan sains. Model tersebut meliputi: (a) variabel bakat siswa meliputi kemampuan/prestasi awal, motivasi/konsep diri dan usia/tingkat perkembangan; (b) variabel instruksional (pengajaran) meliputi kuantitas/waktu dan kualitas pengajaran, dan (c) variabel lingkungan meliputi rumah, ruang kelas, teman, paparan media massa.

Berdasarkan faktor-faktor yang telah dikemukakan dapat disusun upaya yang dikembangkan dari penelitian Topcu (2016: 1724-1727), guru harus menemukan metode strategi mengajar baru untuk mengurangi kecemasan terhadap matematika. Pembentukan konsep yang menyenangkan dapat menjadi strateginya. Pengaitan teknologi dalam memodelkan matematika misalnya, atau dalam tataran yang lebih sederhana yaitu mengaitkan alam sekitar dengan konteks penyelesaian matematika. Hal ini menjadi relevan pada saat pembelajaran tidak lagi dalam ruang kelas. Dengan demikian dapat meningkatkan sikap positif terhadap matematika, siswa menjadi terlibat secara aktif dalam tugas matematika yang bermanfaat yang didesain untuk membangkitkan rasa ingin tahu siswa dan untuk mendalami pemahaman konseptual. Perlu dilakukan edukasi kepada orang tua untuk meningkatkan pengetahuan dan kesadaran terkait pendidikan. Terlebih, pembelajaran daring, praktis dilakukan dari rumah, orang tua memiliki peranan yang sangat besar. Hal ini penting dikarenakan tingkat pendidikan orang tua berkorelasi dengan prestasi siswa sebagaimana dinyatakan oleh Berberoğlu et. al. (Topcu, 2016: 1725). Di sisi lain, orang tua dapat menjadi pendamping (tutor) selama pembelajaran daring di rumah.

Selain itu, Willms (Topcu, 2016: 1725) menyarankan agar administrasi (pengelola) sekolah mendesain lingkungan sekolah dalam cara yang positif dan menarik untuk memotivasi siswa agar semakin bersemangat ke sekolah. Dalam konteks pembelajaran selama pandemic Covid-19, maka penyediaan Learning Management System (LMS) yang bervariasi dan inovatif menjadi salah satu kunci dalam menyajikan materi yang menarik. Di samping didukung dengan media pembelajaran berbasis IT yang tentunya inovatif. Hal ini sejalan dengan definisi PISA baru tentang literasi matematika akan terus mengakui peran penting teknologi informasi dengan mencatat bahwa lebih melek matematis, siswa lebih mampu menerapkan matematika.

Janah, S. R., Suyitno, H., \& Rosyida, I. (2019), menggambarkan abad ke-21 dengan kemajuan ilmu pengetahuan teknologi informasi dan komunikasi, kompetisi global, dan persaingan bebas sehingga menuntut siswa memiliki kecakapan untuk berpikir tingkat tinggi, berpikir kritis, menguasai teknologi informasi, mampu berkolaborasi, dan komunikatif. Dan tidak dapat terelakan lagi, pandemi Covid-19 mempercepat tuntutan siswa untuk lebih cakap terhadap literasi digital. Kehadiran guru dalam proses tatap muka belum dapat terlaksana, sehingga salah satu jalan literasi matematika harus ditopang dengan literasi digital.

Kemampuan pemanfaatan dan penguasaan teknologi informasi menjadi bagian yang tidak terelakan dalam kecapakan abad 21. Stacey, K. (2011) menyebutkan, melalui banyak major dan minor analisis data yang sekarang tersedia untuk umum, PISA menyediakan badan informasi tentang pendidikan dalam matematika. Sehingga kecakapan literasi digital juga merupakan keharusan untuk menopang literasi matematika.

\section{SIMPULAN}

Literasi matematika merupakan salah satu kecakapan abad 21, kemampuan individu untuk memformulasikan, menggunakan, dan menginterpretasikan matematika dalam berbagai konteks khususnya penerapan dalam kehidupan nyata. Dalam menyambut PISA 2021 literasi matematika yang dibarengi kemampuan penalaran matematika, sehingga dapat menarik hubungan konsep matematika dengan pemecahan permasalahan dalam kehidupan nyata, serta memanfaatkan kemajuan teknologi informasi. 
Upaya yang dapat dilakukan dalam rangka pengembangan literasi matematika berkaitan dengan PISA 2021, mengkondisikan siswa untuk terlibat dalam pengalaman belajar pemberian permasalahan pada Higher Order Thinking Skill (HOTS) sehingga akan mengasah kemampuan bernalar siswa.

\section{UCAPAN TERIMA KASIH}

Ucapan terima kasih kepada para reviewer yang akan merevisi sehingga kualitas paper menjadi lebih baik dan tim editor jurnal yang telah bekerja keras untuk mempublikasi paper.

\section{DAFTAR RUJUKAN}

Ehmke, T., van den Ham, A. K., Sälzer, C., Heine, J., \& Prenzel, M. (2020). Measuring mathematics competence in international and national large scale assessments: Linking PISA and the national educational panel study in Germany. Studies in Educational Evaluation, 65, 100847. https://doi.org/10.1016/j.stueduc.2020.100847

Fathani, A.H. (2016). Pengembangan Literasi Matematika Sekolah dalam Perspektif Multiple Intelligences. Edu Sains: Jurnal Pendidikan Sains dan Matematika, 4(2), 136-150. https://doi.org/10.23971/eds.v4i2.524.

Gomes, M., Hirata, G., \& Oliveira, J.B.A. (2020). Student composition in the PISA assessments: Evidence from Brazil. International Journal of Educational Development, 79. https://doi.org/10.1016/j.ijedudev.2020.102299

Janah, S. R., Suyitno, H., \& Rosyida, I. (2019). Pentingnya Literasi Matematika dan Berpikir Kritis Matematis dalam Menghadapi Abad ke-21. PRISMA, Prosiding Seminar Nasional Matematika, 2, 905-910. https://journal.unnes.ac.id/sju/index.php/prisma/article/view/29305

Kaiser, G., \& Sriraman, B. (2006). A global survey of international perspectives on modelling in mathematics education. Zentralblatt für Didaktik der Mathematik, 38, 302-310. https://doi.org/10.1007/BF02652813

Kementerian Pendidikan dan Kebudayaan. (2017) Panduan Implementasi Keterampilan Abad 21 Kurikulum 2013 di SMA. Jakarta: Dit. PSMA Ditjen Pendidikan Dasar dan Menengah.

Mahdiansyah dan Rahmawati. (2014). Mathematical Literacy of Students at Secondary Education Level: An Analysis Using International Test Design with Indonesian Context. Jurnal Pendidikan dan Kebudayaan, 20, 452-469.

Mansur, N. (2018). Melatih Literasi Matematika Siswa dengan Soal PISA. PRISMA, Prosiding Seminar Nasional Matematika, 1 , 140-144. https://journal.unnes.ac.id/sju/index.php/prisma/article/view/19574

Maulana, A., \& Hasnawat, H. (2016). Deskripsi Kemampuan Literasi Matematika Siswa Kelas VIII-2 SMP Negeri 15 Kendari. Jurnal Penelitian Pendidikan Matematika, 4(2), 1-14. http://dx.doi.org/10.36709/jppm.v4i2.3060

NEA. (2011). Preparing 21st Century Students for a Global Society: An Educator's Guide to the "Four Cs". Washington: NEA

OECD. (2016). PISA 2018 Draft Analytical Framework May 2016. Paris: OECD.

OECD. (2016). PISA 2018 Integrated Design. Paris: OECD.

OECD. (2019). Framework for the Assessment of Creative Thinking in PISA 2021: Third Draft. Paris: OECD. 
Ojose, B. (2011). Mathematics Literacy: Are We Able To Put The Mathematics We Learn Into everyday use? Journal of Mathematics Education, 4, 89-100.

Pakpahan, R. (2016). Faktor-faktor yang Memengaruhi Capaian Literasi Matematika Siswa Indonesia Dalam Pisa 2012. Jurnal Pendidikan dan Kebudayaan, 1(3), 331-348. https://doi.org/10.24832/jpnk.v1i3.496

PISA Cycle of Assessments. Retrieved from: https://nces.ed.gov/surveys/pisa/pisa2018/pdf/PISA-Cycle-ofAssessments.pdf

PISA 2021: Mathematics Framework. Retrieved from: https://pisa2021-maths.oecd.org/

Sari, R.H.N. (2015). Literasi Matematika: Apa, Mengapa dan Bagaimana? Prosiding Seminar Nasional Matematika dan Pendidikan Matematika UNY,713-720. http://seminar.uny.ac.id/semnasmatematika/sites/seminar.uny.ac.id.semnasmatematika/files/banne $\underline{\mathrm{r} / \mathrm{PM}-102 . \mathrm{pdf}}$

Stacey, K. (2011). The PISA View of Mathematical Literacy in Indonesia. Indonesian Mathematical Society Journal on Mathematics Education, 2(2), 95-126.

Stacey, K. (2010). Mathematical and Scientific Literacy Around The World. Journal of Science and Mathematics Education in Southeast Asia, 33, 1-16.

Stadler, M., Herborn, K., Mustafić, M., \& Greiff, S. (2020).The assessment of collaborative problem solving in PISA 2015: An investigation of the validity of the PISA 2015 CPS tasks. Computers \& Education, 157. https://doi.org/10.1016/j.compedu.2020.103964.

Syawahid, M., \& Putrawangsa, S. (2017). Kemampuan literasi matematika siswa SMP ditinjau dari gaya $\begin{array}{llll}\text { belajar. Beta: Jurnal Tadris } & \text { Matematika, }\end{array}$ https://doi.org/10.20414/betajtm.v10i2.121

Tjalla, A. (2010). Potret Mutu Pendidikan Indonesia Ditinjau dari Hasil-Hasil Studi Internasional. Diakses dari: http://pustaka.ut.ac.id/pdartikel/TIG601.pdf.

Topcu, M. S. (2016). Factors predicting Turkish and Korean Sttudents' Science and Mathematics Achievement in TIMSS 2011. Eurasia Journal of Mathematic, Science, and Technology Education, 12(7), 1711-1737.

Wulandari, E., \& Azka, R. (2018). MENYAMBUT PISA 2018: PENGEMBANGAN LITERASI MATEMATIKA UNTUK MENDUKUNG KECAKAPAN ABAD 21. De Fermat : Jurnal Pendidikan Matematika, 1, 31-38. https://doi.org/10.36277/defermat.v1i1.14 